\title{
PROFITABLENESS AND PERSPECTIVE OF THE APICULTURE IN NORTH-EASTERN BULGARIA
}

\author{
*Lyubomir Lyubenov, Atanas Atanasov, Ivaylo Hristakov \\ University of Ruse "Angel Kanchev”, Bulgaria \\ *Corresponding author's email: 1lyubenov@uni-ruse.bg
}

\begin{abstract}
The trends in the change of the profitability of Bulgarian beekeeping starting from the country's accession to the European Union (EU) in 2007 to the present 2020, are being studied, depending on the changes in the market price of honey and its prime cost. The survey was conducted among selected apiaries in North-eastern Bulgaria. It has been found that they achieve a small net profit when selling conventional honey in the organizational markets - EUR 3.78 $\mathrm{kg}^{-1}$. The realization of organic honey as a raw material in the organizational markets is not profitable for them. The apiaries have a net profit of EUR $7.98 \mathrm{~kg}^{-1}$ for conventional and EUR $7.91 \mathrm{~kg}^{-1}$ for organic honey, with distribution to a consumer market sale. The apiaries in Ruse district achieve $10.26 \%$ profitability of turnover in sales on conventional consumer markets, $8.83 \%$ in organic consumer markets and $8.2 \%$ in organizational conventional markets. Improving their profitability requires: 1) marketing strategies, through regional and cross-sectoral integration; 2) the production of royal jelly, pollen and propolis with high added value; 3 ) introduction of new technologies, increase in labour productivity, and 4) state subsidies to a hive for ecosystem pollination service.
\end{abstract}

Key words: beekeeping, cost, honey, conventional markets, organic markets, prime cost.

\section{Introduction}

Beekeeping in Bulgaria is the agriculture sector providing the largest alternative employment in depopulated rural areas. The favourable climatic conditions, the rich biodiversity of flowering vegetation and the possibility of funding under National and European programs are a prerequisite for its successful development. In 2019, the number of bee colonies increased by $10.8 \%$ compared to the previous year (Agrostatistics, 2020). The amount of honey produced in the country has increased by $14.5 \%$ compared to 2018. The average honey production per bee colony has decreased by $2.4 \%$ down to 16.4 $\mathrm{kg}$. A decrease was also observed in the amount of sold honey, which is $4.0 \%$ less than in the previous period. Changes were also observed in the number of colonies per apiary, with a $23.9 \%$ increase in the share of apiaries with between 10 and 49 colonies and with $16.1 \%$ of those apiaries with between 50 and 149 colonies. These changes show the expansion of beekeeping production and the desire to turn it into a profitable business.

Despite the positive trends, beekeeping in Bulgaria faces a number of problems related to some changes such as: 1) beekeeping practice, 2) sources of nectar and pollen, 3) meteorological conditions, and 4) the realization of honey yield. The first three groups of changes directly affect the production of honey and pollen and indirectly the profitability of beekeeping production, while the changes related to the realization of honey yield directly affect the income and profitability of apiculture.

Furthermore, the role of bees as pollinators and their influence on agricultural production in Bulgaria is completely neglected. Best practices in beekeeping and pollination management help increase agricultural yield (Bradbear, 2009), (Kumar \& Singh, 2003).
Placing beehives in agricultural land is crucial to optimizing the efficiency of bees in pollinating and harvesting honey bee products (Barnsley Beekeeper Association), (British Beekeepers Association, 2006), (Brosi, Armsworth, \& Daily, 2008).

From 2019, beekeeping in Bulgaria is in a difficult situation by the European Commission decision to accept duty free import of honey from Argentina, Brazil, China, Ukraine and others. (Beekeepers, 2019). This has led to a significant reduction in the purchase price of honey and the profitability of beekeeping production. Trying to increase their incomes, many beekeepers increase the number of bee colonies. However, this requires many more investments, and due to the declining returns from beekeeping, it also leads to a decrease in its profitability. The profitability of the apiaries depends on the profit realized and the means by which it has been obtained. The return on equity is the ratio of net profit to total capital. When the apiaries make more profit with less capital, they will be more profitable. But without profit, the apiaries cannot achieve profitability, even if they invest considerable capital in beekeeping. The profit of each bee product depends on its income and costs. In order to determine the profit per unit of production, the income and expenses per unit of bee product - honey, wax, etc. - are required.

The aim of the study is to determine the profit from conventional and organic honey of farms in Northeastern Bulgaria in the last decade (2011-2019), by analyzing changes in market prices and cost.

\section{Materials and Methods}

The survey was conducted on the basis of data for changes in prices of honey for the period of 2011-2019, obtained from agro-statistic reports to the Ministry of Agriculture, Food and Forestry and information from 
152 beekeepers for the period of 2011-2019, which keep records of their production costs and income of the products sold.

The data on the cost of honey in farms from northeastern Bulgaria for the period 2011-2019 are based on a cluster sample of four nests from Rousse district Nikolovo village, Brestovitsa village, Bazovets village and Yuper village. During the analysed period, as beekeepers, the authors conducted systematic observations in their own and neighbouring apiaries, exchanging information and experience about the cost of honey produced. Lyubenov observed 32 pcs conventional apiaries from the village of Nikolovo, Hristakov 42 pcs organic apiaries from the village of Brestovitsa and 44 pcs from the village of Bazovets, Atanasov 34 pcs conventional apiaries from the village of Yuper, i.e. a total of 86 pcs biological and 66 pcs conventional farms. The results were discussed with beekeeping unions and in the training of beekeepers in the National Agricultural Advisory Service.

The data on honey prices are from agrostatistic governmental and market institutions - Ministry of Agriculture, Food and Forestry (www.mzh. government.bg), National Agricultural Advisory Service (www.naas.government.bg), Agro-market information system (https://sapi.bg). The sources of information about the cost of honey are apiaries in Ruse region and regional branch unions. The methods used are retrospective analysis of prices and costs, monitoring and empirical study of the costs of regional apiaries and focus groups with representatives of industry unions. In Table 5 and 6 , the cost of conventional and organic honey from Ruse region is systematized, synthesized and calculated.

\section{Results and Discussion}

In 2019, the North-eastern Region (Agrostatistics, 2020) had 190,417 colonies and was on the second place after North Central Region. The Ruse region is a part of the North-eastern region and is one of the average territories and population in Bulgaria - its area is about $3 \%$ and the population is about $2.5 \%$ of the national indicators (NSI, 2016). It is in the top 5 of the districts with the largest number of bee families in Bulgaria. The registered hives in the district are about 43,000. The Ruse region produces more than 1,000 tonnes of honey, which is about $10 \%$ of the national production, respectively and a similar part of the realized economic effect of pollination -50 million EUR year-1 (Lyubenov, 2018). The average production of honey from a hive is close to and even above the national level due to the higher relative share of semiprofessional and professional apiaries and favourable economic and geographical conditions. The income per unit of production of honey is dependent on its market price, which the beekeepers cannot influence.

Changes in prices of honey 2011-2014, EUR kg-1

\begin{tabular}{|l|c|c|c|c|}
\hline & \multicolumn{2}{|c|}{ Organizational market } & \multicolumn{2}{c|}{ Consumer Market } \\
\hline \multicolumn{1}{|c|}{ Types of honey } & Conventional & Organic & 6.14 & 7.16 \\
\hline Acacia & 3.58 & 5.11 & 5.11 & 6.14 \\
\hline Lime & 3.07 & 3.58 & 4.09 & - \\
\hline Sunflower & 2.56 & - & 3.58 & 4.60 \\
\hline Multiflora & 2.30 & 3.32 & 3.07 & - \\
\hline Oilseed rape & 2.05 & - & 4.40 & 5.98 \\
\hline Average & 2.71 & 3.99 & & \\
\hline
\end{tabular}

Table 2

Changes in prices of honey 2015-2017, EUR kg-1

\begin{tabular}{|l|c|c|c|c|}
\hline & \multicolumn{2}{|c|}{ Organizational market } & \multicolumn{2}{c|}{ Consumer Market } \\
\hline \multicolumn{1}{|c|}{ Types of honey } & Conventional & Organic & Conventional & Organic \\
\hline Acacia & 3.07 & 4.60 & 6.14 & 7.16 \\
\hline Lime & 2.68 & 3.32 & 5.11 & 6.14 \\
\hline Sunflower & 2.30 & - & 4.09 & - \\
\hline Multiflora & 2.17 & 3.07 & 3.58 & 4.60 \\
\hline Oilseed rape & 1.92 & - & 3.07 & - \\
\hline Average & 2.45 & 3.68 & 4.40 & 5.98 \\
\hline
\end{tabular}


Changes in prices of honey 2018, EUR kg-1

\begin{tabular}{|l|c|c|c|c|}
\hline & \multicolumn{2}{|c|}{ Organizational market } & \multicolumn{2}{c|}{ Consumer Market } \\
\hline \multicolumn{1}{|c|}{ Types of honey } & Conventional & Organic & 5.11 & 6.14 \\
\hline Acacia & 3.58 & 4.09 & 4.09 & 5.11 \\
\hline Lime & 2.56 & 3.32 & 3.58 & - \\
\hline Sunflower & 2.05 & - & 3.58 & 4.60 \\
\hline Multiflora & 2.05 & 3.07 & 3.07 & - \\
\hline Oilseed rape & 1.84 & - & 3.89 & 5.27 \\
\hline Average & 2.40 & 3.48 & & Organic \\
\hline
\end{tabular}

Changes in prices of honey 2019, EUR $\mathrm{kg}^{-1}$

Table 4

\begin{tabular}{|l|c|c|c|c|}
\hline & \multicolumn{2}{|c|}{ Organizational market } & \multicolumn{2}{c|}{ Consumer Market } \\
\hline \multicolumn{1}{|c|}{ Types of honey } & Conventional & Organic & 5.11 & Organic \\
\hline Acacia & 3.58 & 3.58 & 4.09 & 5.14 \\
\hline Lime & 2.45 & 2.71 & 3.58 & - \\
\hline Sunflower & 1.79 & - & 3.58 & 4.60 \\
\hline Multiflora & 1.94 & 2.30 & 3.07 & - \\
\hline Oilseed rape & 1.69 & - & 3.86 & 5.27 \\
\hline Average & 2.30 & 2.86 & & \\
\hline
\end{tabular}

In 2008-2009, the National Beekeeping Program (NBP) was launched in Bulgaria. At that time, honey prices were similar to prices in 2019. National markets for organic honey only developed after 2010, assuming that honey obtained from rapeseed and sunflower cannot be organic. Table 1, Table 2, Table 3, Table 4 outline the market prices in the national organizational and national consumer markets, with their organic and conventional segments. The prices on the national markets are the result of those on the international markets and the beekeepers cannot influence the prices. All markets and their segments have a steady downward trend in market prices for honey.

The cost per unit of production of honey in Ruse region depends on the labour input, and its cost is EUR 62.378 month $^{-1}$, social insurance, depreciation and costs for repair, nutrition, veterinary medicines, packaging, transport and more. The costs of selling of $1 \mathrm{~kg}$ honey are for unpackaging, packaging, transport and marketing. They all form the full unit cost of conventional and organic honey. In Table 5 and Table 6 the basic cost of conventional and organic honey is determined, under the established economic and geographical conditions of production in the region of Ruse. The cost may also be higher, depending on the distance between the apiary and the processing and packaging site, the prices of the factors and the means of production in investigated regions.
The comparison between the self-value costs of the most widely produced conventional and organic honey in the region of Ruse - the multifloral honey Table 5, Table 6 and its market prices Table 1, Table 2, Table 3 and Table 4 show that there are two negative trends for the analysed period. The first is that after Bulgaria's accession to the EU in 2007, there has been a steady increase in the prices and the means of production in Bulgarian agriculture, and thus the cost of agricultural production, including the beekeeping sector of the Ruse region.

The second trend is a steady decline in the prices of conventional and organic honey. At the beginning of the period prices were higher and the cost lower, but at the end of the period they were very close, causing negative or negligible profit and profitability.

These trends lead to a steady decrease in the margin between the market prices of honey and the cost, and thus to profit and profitability. For the analysed period average prices on the conventional markets of conventional honey decreased by EUR $0.409 \mathrm{~kg}^{-1}$, and in the consumer markets by EUR $0.512 \mathrm{~kg}^{-1}$, while in the organizational organic markets they decreased by EUR $1.125 \mathrm{~kg}^{-1}$ and in the consumer markets by EUR $0.716 \mathrm{~kg}^{-1}$. At the same time, the cost is growing steadily, with organic honey growing much higher than conventional production, respectively reducing margins and profits are even greater. 


\section{Expenses of conventional honey in the region of Ruse}

\begin{tabular}{|c|c|c|c|}
\hline Expenses & EUR hive $^{-1}$ & EUR kg-1 & $\%$ \\
\hline 1. Salary (amount of $1.1-1.4=4$ hours) & 14.97 & 0.75 & 37.09 \\
\hline 1.1. Labor - harvesting (removal / return of frames, extracting, filtering - 2 hours) & 7.49 & 0.37 & \\
\hline 1.2. Labor - examinations (basic, swarming, informational, etc. -1 hour) & 3.74 & 0.19 & \\
\hline 1.3. Labor - nourishment ( 0.5 hours) & 1.87 & 0.09 & \\
\hline 1.4. Labor - prevention (varroatosis and other diseases -0.5 hours) & 1.87 & 0.09 & \\
\hline 2. Self - insurance ( $31.3 \%$ of salary) & 4.69 & 0.23 & 11.61 \\
\hline 3. Depreciation ( $10 \%$ of the hive price $)$ & 5.11 & 0.26 & 12.67 \\
\hline 4. Repair ( $3 \%$ of the hive price) & 1.53 & 0.08 & 3.80 \\
\hline 5. Feeding - autumn EUR 5,11, spring EUR 3.07 & 8.18 & 0.41 & 20.27 \\
\hline 6. Medical supplies - autumn / spring EUR 2.05, etc. & 3.07 & 0.15 & 7.60 \\
\hline 7. Unpackaging (tins $-25 \mathrm{~kg}$, etc.) & 1.79 & 0.09 & 4.43 \\
\hline 8. Transport & 1.02 & 0.05 & 2.53 \\
\hline All production cost & 40.36 & 2.02 & 100.00 \\
\hline $\begin{array}{l}\text { 1. Packaging (decrystallization, filtration, homogenization, packaging and } \\
\text { labelling) }\end{array}$ & & 0.46 & \\
\hline 2. Packaging (glass jars, labels) & & 0.18 & \\
\hline 3. Transport & & 0.03 & \\
\hline 4. Marketing (research, advertising, etc.) & & 0.03 & \\
\hline All complete cost price & & 2.71 & \\
\hline \multicolumn{3}{|l|}{ Share of production cost in total } & 74.53 \\
\hline
\end{tabular}

Legend:

Bee hive - Dadant blatt system

Yielding conventional honey bouquet $20 \mathrm{~kg}$ per year.

Hourly payment (1 time min. EUR 311.89) - EUR $3.74 \mathrm{~h}^{-1}$

At the end of the analysed period, the gross profit per unit of production of bee honey in distribution on the national conventional organizational markets was EUR $0.275 \mathrm{~kg}^{-1}$. Farmers in Bulgaria pay a $10 \%$ tax on $40 \%$ of their turnover at $60 \%$ of the normative recognized costs. The net profit in the same markets is EUR $0.185 \mathrm{~kg}^{-1}$. The apiaries in the Ruse region do not realize gross and net profit on organic honey on the national organizational organic markets Table 7. The gross margin for distribution on the consumer conventional markets is EUR $1.15 \mathrm{~kg}^{-1}$. The net profit in the same markets after paying $20 \%$ value added tax on the final price is EUR $0.39 \mathrm{~kg}^{-1}$. The gross margin on sales on the national consumer organic markets is EUR $1.485 \mathrm{~kg}^{-1}$ and the net profit is EUR $0.455 \mathrm{~kg}^{-1}$ - Table. 8 .

The data in Table 7 and Table 8 shows that the apiaries in the Ruse district achieve the highest net profitability of the turnover on the consumer conventional markets $-10.26 \%$. In the consumer organic segment, their profitability was $8.83 \%$, in the conventional organizational segment it was $8.2 \%$, and the organizational organic segment it was unprofitable.
The negative trends in honey prices, which continued to decline in early 2020 and the steady rise in selfvalue cost, has led to a sustainable decline in the profitability of apiaries.

From the data obtained and shown in Table 7 and Table 8, we can also determine the annual net profit of apiaries in the Ruse region. With an average yield of $20 \mathrm{~kg}$ per hive conventional honey and placement on organizational markets, the net profit per hive is EUR 3.78 year $^{-1}$ and in the consumer markets EUR 7.98 year $^{-1}$. With an average yield of $17 \mathrm{~kg}$ per hive of organic honey and placement on the consumer markets, the net profit is EUR 7.91 year $^{-1}$. Therefore, apiaries from Ruse with 1000 hives, which sell honey on the organic consumer markets, will realize a net profit of EUR 790.969 year $^{-1}$, and when sold on the conventional consumer markets EUR 797.615 year $^{-1}$.

Determining the cut-off point (revenue $=$ cost), it also allows the calculation of the hive gross profit. When production costs are relatively constant, the critical point is: 


\section{Expenses of organic honey in the region of Ruse}

Table 6

\begin{tabular}{|c|c|c|c|}
\hline Expenses & EUR hive $^{-1}$ & EUR kg-1 & $\%$ \\
\hline 1. Salary (amount of 1.1. $-1.4=4.2$ hours) & 14.47 & 0.85 & 27.84 \\
\hline 1.1. Labor - harvesting (removal / return of frames, extracting, filtering -2 hours) & 6.89 & 0.41 & \\
\hline 1.2. Labor - examinations (basic, swarming, informational, etc. -1 hour) & 3.45 & 0.20 & \\
\hline 1.3. Labor - nourishment ( 0.5 hours) & 1.72 & 0.10 & \\
\hline 1.4. Labor - prevention (varroatosis and other diseases -0.7 hours) & 1.72 & 0.10 & \\
\hline 2. Self - insurance ( $31.3 \%$ of salary) & 4.53 & 0.27 & 8.72 \\
\hline 3. Depreciation ( $20 \%$ of the hive price) & 10.23 & 0.60 & 19.67 \\
\hline 4. Repair ( $4 \%$ of the hive price) & 2.05 & 0.12 & 3.93 \\
\hline 5. Feeding - autumn EUR 7.67, spring EUR 5.11 & 12.78 & 0.75 & 24.59 \\
\hline 6. Natural medical supplies - autumn /spring EUR 3.07 and others & 5.11 & 0.30 & 9.84 \\
\hline 7. Packaging (tins $-25 \mathrm{~kg}$, etc.) & 1.79 & 0.11 & 3.44 \\
\hline 8. Transport & 1.02 & 0.06 & 1.97 \\
\hline All production cost & 51.98 & 3.06 & 100.00 \\
\hline $\begin{array}{l}\text { 1.Unpackaging (decrystallization, filtration, homogenization, packaging and } \\
\text { labelling) }\end{array}$ & & 0.46 & \\
\hline 2. Packaging (glass jars, labels) & & 0.18 & \\
\hline 3. Transport & & 0.03 & \\
\hline 4. Marketing (research, advertising, etc.) & & 0.03 & \\
\hline All complete cost price & & 3.75 & \\
\hline \multicolumn{3}{|l|}{ Share of production cost in total } & 81.58 \\
\hline
\end{tabular}

Legend:

Bee hive - Dadant blatt system

Yielding an organic honey bouquet $17 \mathrm{~kg}$ per year.

Hourly payment (2 time min EUR 311.89) - EUR $3.74 \mathrm{~h}^{-1}$

Table 7

\section{Profitability of honey in organizational market}

\begin{tabular}{|l|c|c|}
\hline & Conventional & Organic \\
\hline Market Price (), EUR kg-1 & 2.30 & 2.86 \\
\hline Commercial cost (), EUR kg-1 & 2.02 & 3.06 \\
\hline Gross profit (), EUR kg-1 & 0.28 & -0.19 \\
\hline Tax (1), EUR kg-1 & 0.09 & - \\
\hline Net profit (), EUR kg-1 & 0.19 & - \\
\hline Wn per beehive (), EUR year-1. & 3.78 & - \\
\hline Wn per 1000 beehive (), EUR year .1 & 3.783 .56 & - \\
\hline Profitability of turnover ).100, \% & 4.19 & - \\
\hline
\end{tabular}

$$
\begin{aligned}
& Q b=\frac{S m}{\mathrm{Pe}} \\
& W m=P e-S m
\end{aligned}
$$

(1) At an average yield of $20 \mathrm{~kg}$ per hive of honey, the critical point is $Q b=S m .20 / P e$. In the market for organizational conventional markets $Q b=3.95 .20$ /

(2) $4.5=17.55 \mathrm{~kg}$. Apiaries in the Ruse region will start to make a gross profit of more than $17.55 \mathrm{~kg} \mathrm{hive}^{-1}$. At an average yield of $20 \mathrm{~kg}$, gross profit $\mathrm{Wm}=(20-$ Legend:

$Q b$ - critical point; $\mathrm{Sm}$ - production cost; $P e$ - market price; $W m-$ gross profit 17.55) $.4 .5=$ EUR 5.625 hive $^{-1}$. Therefore, apiaries 
Profitability of honey in consumer markets

\begin{tabular}{|l|c|c|}
\hline & Conventional & Organic \\
\hline Market Price (), EUR kg-1 & 3.89 & 5.27 \\
\hline Commercial cost (), EUR kg-1 & 2.71 & 3.75 \\
\hline Gross profit (), EUR kg-1 & 1.18 & 1.52 \\
\hline Tax (), EUR kg-1 & 0.78 & 1.05 \\
\hline Net profit (), EUR kg-1 & 0.40 & 0.47 \\
\hline Wn per beehive (), EUR year-1. & 7.98 & 7.91 \\
\hline Wn per 1000 beehive (), EUR year .1 & 7.976 .15 & 7.909 .69 \\
\hline Profitability of turnover ().100, \% & 5.25 & 4.51 \\
\hline
\end{tabular}

from Ruse with 1000 hives, which sell honey on the conventional organizational markets, will make a gross profit of EUR 562.421 year $^{-1}$.

The apiaries cannot independently influence honey prices, and in order to improve their income and profitability, they must reduce their costs. This can be done in two main ways - extensive and intensive. The first is based on quantitative factors through which the advantages of the wholesale over small production are realized, and the second on the qualitative factors an increase in the average hive yield, selection of bee colonies, improvement of the quality of honey produced, a more complete production capacity utilization, etc.

Large beekeeping production creates better conditions for the application of science and technology, for the introduction of high-performance machinery, technologies and complex forms of cooperation and division of labour, advanced technology and organization of production and marketing. Apiaries in the Ruse district can achieve this by integrating and intensifying production - achieving higher rates of productivity growth than those of the average wage, introducing better technologies and more.

The apiaries must pursue a targeted sectoral policy to introduce beehive subsidies due to two serious arguments: 1) providing an ecosystem-based pollination service, which has a fundamental role and importance for the conservation of biodiversity and the sustainable development of agriculture; 2) improving the profitability of apiaries, taking into account negative and much lower values compared to other sectors - industrial, services, etc. They are also in line with the implementation of a social agricultural policy for providing healthy food at affordable prices.

The apiaries should not rely solely on state and Community policies. They need to develop marketing strategies that allow them to achieve competitiveness and profitability in the markets for bee products (pollen, royal jelly, etc.) and their specific segments - target markets. It is necessary to design high valueadded bee products that allow higher and more sustainable prices. The apiaries should be integrated into a regional, horizontal and vertical plan - with industries to reduce the cost of bee products.

We can summarize that the main role in reducing the cost of apiaries is the introduction of better technologies and organization, the achievement of higher labour productivity, the increase in the average hive production and the regional integration of apiaries that facilitates them. The main factors for increasing the revenues are the achievement of higher prices, provision of subsidies - pollination, etc., diversification of activities - promoting tourism, trade, etc. Marketing plays a key role in increasing the income of apiaries.

\section{Conclusions}

1. The surveyed market prices and the prime cost of honey from apiaries in the region of Ruse show that they achieve a small net profit when selling conventional honey on the organizational markets - EUR $3.78 \mathrm{~kg}^{-1}$. The placement of organic honey as a raw material on the organizational markets is not profitable for them. In the distribution of consumer markets, they reach a net profit of EUR $7.98 \mathrm{~kg}^{-1}$ for conventional and EUR $7.91 \mathrm{~kg}^{-1}$ for organic honey. In an organic farm with 1000 hives, it is EUR 790.969 i.e. very low.

2. The apiaries in the Ruse region have $10.26 \%$ commercial profitability of the costs in marketing to conventional consumer markets, $8.83 \%$ in organic consumer markets and $8.2 \%$ in organizational conventional markets. Organic honey sales, as a raw material on organizational markets are unprofitable. Given the high volatility of honey prices, there are periods in which costeffectiveness will be much lower.

3. The downward trend in bee market prices and the increase in its cost price lead to a decrease in profitability of the business. Measures must 
be taken to stabilize prices and reduce costs. Horizontal and vertical integration of apiaries is needed in order to achieve competitiveness and profitability. Markets and marketing set the directions for integration.

4. Sectoral and cross-sectoral integration will improve revenues by forming bee products with high added value and high sustainable prices, diversification of incomes, preservation of biodiversity, subsidies - pollination and more. It will reduce prime cost by realizing the wholesale advantages prior to small-scale production that allow for better specialization, better technology, higher productivity and higher hive yields.

5. Increasing the profitability of apiaries requires: 1) marketing strategies to achieve profitability and competitiveness at the trans-regional level through regional and cross-sectoral integration, 2) the production of bee products with high added value, incl. outside the category of traditional and most widely produced honey and wax, 3 ) introduction of new technologies, increase in labour productivity and average hive production, and 4) state subsidies assigned to a hive for ecosystem pollination service.

\section{Acknowledgements}

This research is supported by Bulgarian National Science Fund under Project KP-06-PN 46-7 Design and research of fundamental technologies and methods for precision apiculture.

\section{References}

Agrostatistics. (2020). Beekeeping in Bulgaria in 2019, № 368, Retrieved February 11, 2020, from https://www. mzh.government.bg/media/filer_public/2020/02/11/agrarian_report_2019.pdf.

Barnsley Beekeeper Association, Keeping Bees - Apiary Set Up. Retrieved August 16, 2020, from http://barnsleybeekeepers.org.uk/index.php/keeping-bees/apiary-setup.

Beekeepers: The European Market May Close Door for Bulgarian Honey (2019). Retrieved October 20, 2020 , from https://www.novinite.com/articles/199179/Beekeepers\%3A+The+European+Market+May+Close+ Door+for+Bulgarian+Honey.

Bradbear, N. (2009). Bees and their role in forest livelihoods: A guide to her services provided by bees and the sustainable harvesting, processing and marketing of their products. Rome: Food and Agriculture Organization of the United Nations. Retrieved October 12, 2020, from http://www.fao.org/3/a-i0842e.pdf.

British Beekeepers Association. (2006). Choosing an Apiary site. British Beekeepers Association Advisory Leaflet B11 $3^{\text {rd }}$ ed. Warwickshire, UK: British Beekeepers Association. Retrieved November 12, 2020, from https://www.bbka.org.uk/.

Brosi, B.J., Armsworth, P.R., \& Daily, G.C. (2008). Optimal design of agricultural landscapes for pollination services. Conservation Letters, 1(1), 27-36.

Lyubenov, L. (2018). SWOT analysis of beekeeping in the Ruse region, Journal of Mountain Agriculture on the Balkans, 21 (6), 10-27, Retrieved May 12, 2020, from https://www.cabdirect.org/cabdirect/ abstract/20203075310.

National Statistical Institute (NSI). (2016). Retrieved May 12, 2020, from https://www.nsi.bg/en/content/13896/ basic-page/national-statistical-programme-2016.

Kumar, M., \& Singh, R. (2003). Pollination efficiency of Apis mellifera in seed production of sunflower (Helianthus annuus L.). Journal of Entomological Research, 27 (2): 131-134. 